\title{
Editorial Introduction: Putting Virtues Into Practice. A Challenge for Business and Organizations
}

\author{
Joan Fontrodona $\cdot$ Alejo José G. Sison • \\ Boudewijn de Bruin
}

Received: 5 February 2013/ Accepted: 11 March 2013/Published online: 23 April 2013

(C) Springer Science+Business Media Dordrecht 2013

Recent years have witnessed an increasing interest in virtue ethics and its application to business (Hartman 2006, 2008; Koehn 1995, 1998; Solomon 1992, 1993, 2003; Whestone 2001). "Virtue ethics"—as opposed to utilitarian and consequentialist ethics, on the one hand, and deontological ethics, on the other-puts special emphasis on the development of moral character. This makes virtue ethics an excellent platform from which to analyze various aspects of human action, professional work, and business activity.

Some authors have focused on the individual level, showing how virtue ethics can provide insight into how managers behave and make decisions (Arjoon 2010; Bastons 2008; Bertland 2009; Jennings 1991; Parkan 2008; Provis 2010; Whetstone 2003). In fact, through their work, human beings not only produce goods and services but also, and more importantly, develop a series of abilities and

Note To preserve the integrity of the editorial process, the editors of the special issue played no role in the review of their corresponding papers.

J. Fontrodona ( $₫)$

Business Ethics Department, IESE Business School, Avda.

Pearson, 21, 08034 Barcelona, Spain

e-mail: jfontrodona@iese.edu

\author{
A. J. G. Sison \\ Department of Philosophy, University of Navarra, Edificio de \\ Bibliotecas, 31080 Pamplona, Spain \\ e-mail: ajsison@unav.es \\ B. de Bruin \\ Faculty of Economics and Business, University of Groningen, \\ Nettelbosje 4, 9747 AE Groningen, The Netherlands \\ e-mail: b.p.de.bruin@rug.nl \\ B. de Bruin \\ Faculty of Philosophy, University of Groningen, Oude \\ Boteringestraat 52, 9712 GL Groningen, The Netherlands
}

competences that shape their personalities. Human beings not only transform their environment through their work but they also transform themselves.

Most people undertake their professional activity in a business context. Goods and services offered by businesses are produced through the joint effort of people working together. Businesses create environments that can either favor or hinder the personal development of workers. For those reasons, other authors have chosen to write on virtues on the organizational level (Drake and Schlachter 2008; Dyck and Wong 2010; Moore 2005a, b; Sandin 2009).

Third, through their products and services, businesses make an impact on society. People in business should ask themselves how their work and their products or services contribute to building better societies and better citizens. Some products are clearly dangerous to people and societies; other products are controversial at the least; but most of them have a positive impact, although in various degrees. Hence, virtues may also be considered relevant for their bearing on communities and societies as a whole (González 2003; Graafland 2010; Wells and Graafland 2012).

In summary, virtue ethics provides managers and business leaders with an opportunity to ask themselves what kind of people they become through their actions and how their decisions impact the lives of others. It gives them a chance to consider what kind of business environments and cultures they should build, how business goals, policies and procedures foster positive or negative learning in their employees and what kind of societies they contribute to developing through their operations and the products and services they offer.

Virtue ethics is not only a theoretical approach that makes for interesting comparison with other ethical theories (Arjoon 2008; Chan 2008; Everett et al. 2006; Heugens 
et al. 2006; Jensen 2009; Maguire 1997; McCracken and Shaw 1995; McGowan and McGowan 2011; Mele 2009; Solomon 1992; Swanton 2010), it also has a practical dimension as it offers new insights to managers and business leaders regarding their responsibilities toward themselves and their families, the business community, and global civil society at large.

The articles in this special issue of the Journal of Business Ethics cover these different levels of analysis and perspectives. Some take a more theoretical approach to shed light on business practice. Others are practical, both in their approach and the methodology used. Some focus on individual decision making, others analyze corporations, and still others reflect on the society in which companies operate.

In the first article, Crossan et al. (2013) suggest deficiencies in existing decision-making models and present a more comprehensive model that integrates virtues, values, character strengths, and ethical decision making. Following are three articles that propose different and innovative approaches to theoretical concepts from ethics, thereby changing the impact these concepts may have on business. De Bruin (2013) presents a view of epistemic virtues that enhances our understanding of the role played in business by knowledge acquisition and shows that the moral responsibilities of managers also pertain to information gathering and processing. Dierskmeier (2013) reviews Kant's moral philosophy, especially in regard to questions of personal character and moral sentiments, and leads to a more favorable view of its relevance to managerial practice. Sison and Fontrodona (2013) build on the concept of common good of the firm and explore how the various stakeholders contribute toward and participate in it.

The next two articles link theory and practical business aspects. Alves and Moreira (2013) analyze Domingo de Soto's virtue-based approach and his ethical evaluation of commerce in three levels: individual character, commercial practices, and contribution to the common good. Das Neves and Vaccaro (2013) apply insights from Thomas Aquinas to the issue of corporate transparency, and provide a virtue-ethical view for a moral justification of managerial information disclosure.

The last three articles take an empirical approach. Robinson et al. (2013) explore the asymmetry effects in evaluating side effects of managerial decisions and the influence of norm compliance. Karakas and Sarigollu (2013) use narrative inquiry to explore the role and potential of benevolent leadership in creating virtuous and compassionate organizations. Also adopting a narrative approach, Beadle (2013) considers the virtue of constancy and its relation to work as a calling in a study of managers of traditional touring circuses.
The call for papers that led to this special issue of The Journal of Business Ethics received many responses, far exceeding our expectations. We want to thank all the authors who submitted proposals and the reviewers for their assistance in selecting papers. We also thank the Journal's editorial team for its support. We are confident that the articles presented here will make a significant contribution to the development of virtue ethics in practice.

Note To preserve the integrity of the editorial process, the editors of the special issue played no role in the review of their corresponding papers.

\section{References}

Alves, A. A., \& Moreira, J. M. (2013). Virtue and commerce in Domingo de Soto's thought: Commercial practices, character and the common good. Journal of Business Ethics. doi: 10.1007/s10551-013-1681-7.

Arjoon, S. (2008). Reconciling situational social psychology with virtue ethics. International Journal of Management Reviews, 10(3), 221-243.

Arjoon, S. (2010). Aristotelian-thomistic virtue ethics, emotional intelligence and decision-making. Advances in Management, $3(4), 7-13$.

Bastons, M. (2008). The role of virtues in the framing of decisions. Journal of Business Ethics, 78(3), 389-400.

Beadle, R. (2013). Managerial work in a practice-embodying institution - the role of calling, the virtue of constancy. Journal of Business Ethics. doi:10.1007/s10551-013-1678-2.

Bertland, A. (2009). Virtue ethics in business and the capabilities approach. Journal of Business Ethics, 84(Supplement 1), 25-32.

Chan, G. (2008). The relevance and value of Confucianism in contemporary business ethics. Journal of Business Ethics, 77(3), 347-360.

Crossan, M., Mazutis, D. D., \& Seijts, G. (2013). In search of virtue: The role of virtues, values and character strengths in ethical decision making. Journal of Business Ethics. doi: 10.1007/s10551-013-1680-8.

das Neves, J. C., \& Vaccaro, A. (2013). Corporate transparency: A perspective from Thomas Aquinas' summa theologiae. Journal of Business Ethics. doi:10.1007/s10551-013-1682-6.

de Bruin, B. (2013). Epistemic virtues in business. Journal of Business Ethics. doi:10.1007/s10551-013-1677-3.

Dierksmeier, C. (2013). Kant on virtue. Journal of Business Ethics. doi:10.1007/s10551-013-1683-5.

Drake, M., \& Schlachter, J. (2008). A virtue-ethics analysis of supply chain collaboration. Journal of Business Ethics, 82(4), 851-864.

Dyck, B., \& Wong, K. (2010). Corporate spiritual disciplines and the quest for organizational virtue. Journal of Management, Spirituality \& Religion, 7(1), 7-29.

Everett, J., Neu, D., \& Rahaman, A. (2006). The global fight against corruption: A foucaultian, virtues-ethics framing. Journal of Business Ethics, 65(1), 1-12.

González, A. M. (2003). Ethics in global business and in a plural society. Journal of Business Ethics, 44(1), 23-36.

Graafland, J. (2010). Do markets crowd out virtues? An Aristotelian framework. Journal of Business Ethics, 91(1), 1-19.

Hartman, E. (2006). Can we teach character? An Aristotelian answer. Academy of Management Learning \& Education, 5, 68-81. 
Hartman, E. (2008). Socratic questions and Aristotelian answers: A virtue-based approach to business ethics. Journal of Business Ethics, 78(3), 313-328.

Heugens, P. P. M. A. R., Kaptein, M., \& van Oosterhout, J. (2006). The ethics of the node versus the ethics of the dyad? Reconciling virtue ethics and contractualism. Organization Studies, 27(3), $391-411$

Jennings, B. (1991). The regulation of virtue: Cross-currents in professional ethics. Journal of Business Ethics, 10(8), 561-568.

Jensen, K. (2009). Shadow of virtue: On a painful if not principled compromise inherent in business ethics. Journal of Business Ethics, 89(1), 99-107.

Karakas, F., \& Sarigollu, E. (2013). The role of leadership in creating virtuous and compassionate organizations: Narratives of Benevolent leadership in an Anatolian tiger. Journal of Business Ethics. doi:10.1007/s10551-013-1691-5

Koehn, D. (1995). A role of virtue ethics in the analysis of business practice. Business Ethics Quarterly, 5(3), 533-539.

Koehn, D. (1998). Virtue ethics, the firm, and moral psychology. Business Ethics Quarterly, 8(3), 497-513.

Maguire, S. (1997). Business ethics: A compromise between politics and virtue. Journal of Business Ethics, 16(12/13), 1411-1418.

McCracken, J., \& Shaw, B. (1995). Virtue ethics and contractarianism: Towards a reconciliation. Business Ethics Quarterly, 5(2), 297-312.

McGowan, R. J., \& McGowan, T. R. (2011). Locke, business ethics textbooks, and virtue. Journal of Leadership, Accountability \& Ethics, 8(3), 71-76.

Mele, D. (2009). Integrating personalism into virtue-based business ethics: The personalist and the common good principles. Journal of Business Ethics, 88(1), 227-244.

Moore, G. (2005a). Humanizing business: A modern virtue ethics approach. Business Ethics Quarterly, 15(2), 237-255.
Moore, G. (2005b). Corporate character: Modern virtue ethics and the virtuous corporation. Business Ethics Quarterly, 15(4), 659-685.

Parkan, B. (2008). Professionalism: A virtue or estrangement from self-activity? Journal of Business Ethics, 78(1/2), 77-85.

Provis, C. (2010). Virtuous decision making for business ethics. Journal of Business Ethics, 91(2), 3-16.

Robinson, B., Stey, P., \& Alfano, M. (2013). Virtue and vice attributions in the business context: An experimental investigation. Journal of Business Ethics. doi:10.1007/s10551013-1676-4.

Sandin, P. (2009). Approaches to ethics for corporate crisis management. Journal of Business Ethics, 87(1), 109-116.

Sison, A. J. G., \& Fontrodona, J. (2013). Participating in the common good of the firm. Journal of Business Ethics. doi: 10.1007/s10551-013-1684-4.

Solomon, R. C. (1992). Corporate roles, personal virtues: An Aristotelian approach to business ethics. Business Ethics Quarterly, 2(3), 317-339.

Solomon, R. C. (1993). Ethics and excellence: Cooperation and integrity in business. New York: Oxford University Press.

Solomon, R. C. (2003). Victims of circumstances? A defense of virtue ethics in business. Business Ethics Quarterly, 13(1), 43-62.

Swanton, C. (2010). Heideggerian environmental virtue ethics. Journal of Agricultural and Environmental Ethics, 23(1/2), $145-166$

Wells, T., \& Graafland, J. (2012). Adam Smith's bourgeois virtues in competition. Business Ethics Quarterly, 22(2), 319-350.

Whestone, J. T. (2001). How virtue fits within business ethics. Journal of Business Ethics, 33(2), 101-114.

Whetstone, J. T. (2003). The language of managerial excellence: Virtues as understood and applied. Journal of Business Ethics, 44(4), 343-357. 